\title{
THE DIARY OF FLORENCE ATKINSON,
}

\section{3-1886}

\author{
BY EUGENE G. SHARKEY
}

Mr. Sharkey is a graduate student in the Rutgers College Department of History

$I^{1}$ $\mathrm{N}$ the Special Collections department of the Rutgers Library are five small file boxes containing the diaries, notebooks, genealogical records and other private papers of the Atkinson family of New Brunswick. Two notebooks measuring approximately five inches by eight inches contain the diary of Florence Atkinson for the years I 884 and I 885 while she taught school in Argentina.

As part of his intensive campaign to reform the Argentine educational system along the lines of the United States system, Domingo Sarmiento invited North Americans to teach in Argentina. On July 24, 1883, Florence Atkinson, her sister Sarah and fifteen other young women who responded to the invitation, sailed from New York for Liverpool, England aboard the United States mail steamer "Alaska." There was no direct passenger service from New York to Buenos Aires. The sailing program containing a roster of the passengers is posted in the front of the dairy. In similar fashion, throughout the diary, Miss Atkinson attached wedding notices, school examination schedules and other items of interest as she collected them. The first day at sea, the seventeen girls gathered to practice Spanish but, after ten minutes, the excitement of the trip proved too great and they gave up the attempt for the remainder of the voyage. When they arrived in England, they discovered that the ship to Buenos Aires would be delayed two weeks. The women spent the time touring England and visiting Paris. The voyage to Buenos Aires aboard the "Maskelyne" was made in very rough weather in the company of a party of Welsh emigrants bound for Patagonia. Miss Atkinson provides articulate and vivid description of the people, places and events encountered throughout her two years abroad; the best example during the trip to Argentina is the initiation ceremony imposed upon novice seamen when the "Maskelyne" crossed the Equator. She stated that although the second leg of the trip 
lasted three weeks, she could not yet speak Spanish adequately upon arrival in Buenos Aires. The capital seemed shabby to the young teacher, with poorly paved roads and most houses of only one story.

On September 25, 1883, the few teachers who were assigned to duty in San Juan left Buenos Aires by train for Campana, transferred there to boats which carried them up the Paraná to Rosario, thence by train to Mendoza. The description of the pampas and of the increasingly poor living conditions encountered as they progressed inland are quite vivid. At San Luis, the teachers were housed overnight in a mud hotel which Miss Atkinson considered filthy but "no surprise in the Argentine Republic." The comment exemplifies an attitude of condescending tolerance toward the country and its people which is reflected throughout the narrative. She regarded the food served at post-houses as uniformly greasy and onion flavored. At La Paz, the bedbugs were so dense that the innkeeper had to sweep them from the pillows. Between $\mathrm{La} \mathrm{Paz}$ and Mendoza, the land was barren, the carcasses of starved animals were everywhere and only vultures seemed to thrive. She describes the poor condition of the underfed, overworked coach horses and the incredibly barbaric treatment accorded them by their drivers who seemed oblivious to their suffering.

After passing through Mendoza which was new and clean, having been entirely rebuilt following the earthquake of $\mathrm{I} 86 \mathrm{I}$, the teachers arrived in San Juan on October I, I883 and were greeted by the United States teachers already working there. From this point, most of the diary is descriptive of the people and activities of San Juan and of the girls' Normal School of San Juan to which Miss Atkinson was assigned.

She assumed her duties in November, by which time she felt much more at ease with the Spanish language. It was examination time and while serving as a proctor she was offended by the conduct of teachers and students alike, a sense which increased during the next two years. She found the "scholars" purposeful in their studies but willing to cheat if preparation failed (evidently she regarded this all too universal failing as peculiar to Latin America). She regarded the Argentine teachers as permissive in their attitude toward such irregularities. She added that those taking the examinations were of the "elite of San Juan." 
In mid-March, I884, while at his home in San Juan, Governor Anaclieto Gil was shot and seriously wounded by gunmen who killed one of his chief assistants. Miss Atkinson related that local opinion accused members of the opposition party within the state, led by one Burgoa who succeeded in escaping to Chile. Later in her narrative, she mentions that it was rumored Burgoa had been personally rewarded by President Roca for killing the Governor's associate who had aspired to greater power and thereby offended the Roca faction. It is reflective of her poor appreciation of the intraArgentine political situation that Miss Atkinson regarded this and all other acts of political discord or violence as being "revolutions."

In May, I 884, 86-year-old Domingo Sarmiento visited San Juan. The diary indicates that the visit was ostensibly social and he was received with complete deference although some cynics maintained that he had merely come to build his political fences preparatory to seeking a senatorship. Miss Atkinson stated that at a dinner given in honor of Sarmiento she dutifully "laughed at all the old man's jokes" but found him to be "conceited."

At this time, the diary shows that her disenchantment became more pronounced, although at no time did it become extreme or bitter in tone. She complained of the increasingly cold weather and of having to pay higher rent than originally contracted. She dwelt upon what she considered the thinly disguised resentment of most Argentines toward North Americans. Observing the pomp and circumstance of the frequent religious feast days when the wealthy women promenaded in dresses costing up to $\$ 500$, she was unable to reconcile such circumstances with the general poverty of the population. Additionally, she was offended by minor circumstances such as the habit of permitting dogs to run loose in church. She declared her hope to be able to leave the country before the Presidential elections of 1886 when she fully expected a major revolution to erupt.

One very important observation is not sufficiently pursued. She noted that the staff of the school feared that upon the return of the Bishop of Cuyo from a conference in Córdoba, he "may attack us but I think not as he has always been in favor of the school. . . . However if the clergy succeed in expelling the North Americans, I for one shall not weep very much. The Government stands up for 
us so perhaps in a few years there will be a separation of Church and State in the Argentine Republic." Further comment on the manifestations of this crucial national problem as reflected in the microcosm of San Juan would be very valuable but Miss Atkinson made no further comment beyond including an editorial from La Unión which reflects the antagonism of the Catholic clergy toward the Protestant controlled normal schools.

In December, I 884, she visited the boys' National College in San Juan. She found the mechanical equipment for study of the sciences and the extensive library equivalent to anything she knew in the United States. Some foreign teachers she considered very competent but regarded the majority of Argentine professors as recipients of unjustified government favoritism in obtaining their appointments. The examinations she considered farcical. By way of comparison she mentioned that at her school a fair, strict system had been attained "to the surprise of the girls as a great many did not pass" and to one in particular who shocked Miss Atkinson by calling one of the teachers a "bruta gringa."

One of the most descriptive parts of the diary is of her trip to Chile during January, February and March of $\mathrm{I} 885$ in company with several teachers and other travellers, the most notable of whom was an Englishman whom she described as "fair, fat and forty" but with whom, despite those drawbacks, she established a close friendship. She described the Andes and the many vistas from the mountains in truly vivid fashion and in her diary pressed samples of various flowers which are today in surprisingly good condition considering that they have lain there 90 years. Upon discovering the warship "USS Hartford" in Valparaiso harbor she rushed aboard with evident relief and was dined by the officers before she continued her trip. Her description of the city of Santiago de Chile is quite good and she frequently used Spanish rather than English descriptive terms.

In April, I 885, after her return to San Juan, the railroad line reached the town and an exposition was given in tribute to the accomplishment which was seen as the key to the area's prosperity. President Roca and numerous other politicians gathered but Miss Atkinson believed that everyone expected a revolution "as the San Juaninos are noted as assassins." When the first train arrived it was inaugurated by Roca and blessed by the Bishop of Cuyo but, " $[\mathrm{t}]$ here was very little excitement shown by the people. A few feeble cheers 
greeted the President's speech and that was all." These observations led her to a general condemnation of national politics. Noting that state elections were severely controlled by armed guards of the party in power and that the dissidents were frequently imprisoned prior to elections, Miss Atkinson continued:

Opposition parties are anxious to get into politics on account of the high salaries paid to Deputies and Senators for doing nothing. The Senators are paid $\$ 5,000$ a year for nine years and do nothing but uphold the governing party. To this end the President makes Governors and Senators of young and unexperienced (sic) men who will obey him and do just as he pleases. The same happens in the provinces. The governor and chief officers of San Juan are young men and mulatoes (sic), the greater part, tools of Roca. ... The nations of Spanish blood are so excitable that anything like a settled government is out of the question.

In December, 1885 , she declared herself to be completely "disgusted with this country" and eager to return home. When she received notification of her grandmother's death a month later, her resolve became firm and she made immediate departure preparations.

There are several noteworthy aspects to this last portion of the diary. It is entitled the "Triumphal March to the Sea." Whereas the entire previous portion had been written in ink with a very careful hand, the writing is now in purple pencil and in a very careless, although still legible, manner seemingly indicative of great excitement. She finally embarked from Montevideo with the parting comment that the city was "cleaner \& more healthy than Buenos Aires." Her ship, carrying hides, tallow and beef sailed for New York via Rio de Janeiro and Bahia where it off-loaded beef and loaded coffee. At Rio she commented on "the most striking difference being the negroes one sees at every turn." She arrived in New Brunswick May 8 , I 886 , rather more disillusioned than when she had left three years earlier.

The diary of Florence Atkinson reflects the stereotyped image of the i gth century liberal. Philosophically well-intentioned, she was, in practice, incapable of assimilating people and circumstances foreign to her Anglo-American background. When she discovered that the provincial Argentines were very different from North Americans and that they could not or would not embrace those changes necessary to change them into North Americans, she retreated in disillusionment. 